\title{
Characteristics and in Hospital Clinical Outcome of Patients with Non St-Segment Elevation Myocardial Infarction with Chronic Kidney Disease
}

\author{
C M S Kabir ${ }^{1}$, F N Malik² , A Malik² , M M Haq ${ }^{1}$, SDM Taimur ${ }^{1}$, M Jahan ${ }^{3}$ \\ ${ }^{1}$ Department of Cardiology, Ibrahim Cardiac Hospital \& Research Institute, Dhaka, ${ }^{2}$ Department \\ of Cardiology, National Heart Foundation Hospital \& Research Institute, Dhaka, ${ }^{3}$ Department of \\ Radiology \& Imaging, Holy Family Red Crescent Medical College \\ \& Hospital, Dhaka.
}

Key words:

Non ST-Segment

Elevation

Myocardial

Infarction;

Chronic Kidney

Disease.

\begin{abstract}
Background: Nearly $40 \%$ of patients presenting with Non ST-Segment Elevation Myocardial Infarction (NSTEMI) have Chronic Kidney Disease (CKD). CKD is a powerful predictor of adverse events among NSTEMI patients. The purpose of the present study was to evaluate the in-hospital outcome of patients with Chronic Kidney Disease presenting with Non ST-Segment Elevation Myocardial Infarction.

Methods: In this prospective observational study a total of 128 patients with NSTEMI were enrolled. They were divided equally in group I (NSTEMI with CKD) and group II (NSTEMI with normal renal function) on the basis of estimated glomerular filtration rate. Patients were considered to have CKD if he/she had documented history of CKD or estimated glomerular filtration rate $<60 \mathrm{~mL} / \mathrm{min} / 1.73 \mathrm{~m}^{2}$. Presence of inhospital complications was identified.
\end{abstract}

Results: Patients with CKD were significantly older, with a greater prevalence of hypertension, diabetes mellitus, lower left ventricular ejection fraction, and lower haemoglobin level compared with those without CKD. CKD patients had more atypical presentation during admission. In-hospital complications were significantly higher in CKD patients presenting with NSTEMI.

Conclusion: CKD strongly predicts adverse in-hospital outcome among NSTEMI patients.

(Cardiovasc. j. 2013; 5(2): 146-153)

Introduction:

We know that nearly $40 \%$ of patients presenting with Non ST-Segment Elevation Myocardial Infarction (NSTEMI) have Chronic Kidney Disease (CKD). ${ }^{1} \mathrm{CKD}$ is a powerful predictor of adverse events among NSTEMI patients. ${ }^{2}$ CKD patients have a high prevalence of obstructive coronary artery disease (CAD). The severity of CAD and lesion complexity progressively increased as estimated GFR decreased. ${ }^{3}$ Rapid risk stratification is crucial for appropriate management of these patients and for targeting more potent and invasive therapies for higher risk patients. ${ }^{4}$ Objective of the study was to compare the in-hospital outcome among patients of Non ST-Segment Elevation Myocardial Infarction with Chronic Kidney Disease.

\section{Methods:}

This study was conducted in the Department of Cardiology of the National Heart Foundation Hospital and Research Institute, Dhaka, Bangladesh during the period of June 2010 to May 2011. A total of 128 patients with NSTEMI were enrolled. They were divided equally in group I (NSTEMI with CKD) and group II (NSTEMI with normal renal function) on the basis of estimated glomerular filtration rate.

Patients of both sexes with Non ST-Segment Elevation Myocardial Infarction with chronic kidney disease $\left(\mathrm{eGFR}<60 \mathrm{~mL} / \mathrm{min} / 1.73 \mathrm{~m}^{2}\right)$ and without chronic kidney disease (eGFR $\geq 60 \mathrm{~mL} /$ $\mathrm{min} / 1.73 \mathrm{~m}^{2}$ ) were included in the study. Patients with ST-Segment Elevation Myocardial Infarction, unstable Angina, prior MI, PCI, $\mathrm{CABG}, \mathrm{CHF}$, congenital and valvular heart

Address of Correspondence: Dr. CM Shaheen Kabir, Department of Cardiology, Ibrahim Cardiac Hospital \& Research Institute, Dhaka, Bangladesh. Email: skabir67@yahoo.com 
disease, cardiomyopathy, end Stage Kidney Disease requiring Renal Replacement Therapy, extremely severe concomitant disease (severe dementia, advanced malignancy) were excluded from the study.

Acute NSTEMI was diagnosed according to the criteria of the ACCF/AHA. ${ }^{5}$ Chronic kidney disease is defined as either kidney damage or glomerular filtration rate $<60 \mathrm{ml} / \mathrm{min} / 1.73 \mathrm{~m} 2$ for $\geq 3$ months according to the National Kidney Foundation Kidney Disease Outcomes Quality Initiative (KDOQI) guidelines 2002. ${ }^{6}$ Informed written consent was taken from each patient before enrollment. Meticulous history was taken regarding symptoms (chest pain or dyspnoea) and detailed clinical examination was performed. Demographic data and risk factors were recorded for all patients. Patient's baseline 12 lead ECG and Echocardiography were performed. Blood sample was taken for biochemical investigations including Troponin $\mathrm{I}, \mathrm{Hb} \%$ and Serum creatinine. Serum creatinine, lean body weight, gender and age were used to determine estimated GFR by Cockcroft and Gault formula. ${ }^{7}$ Patients were stratified into 2 groups according to estimated GFR. Patients were followed up throughout their hospital stay up to discharge and occurrence of MACEs and complications, if any noted.

All necessary approval to perform the study was obtained from the Academic Council of National Heart Foundation Hospital and Research Institute, Dhaka, Bangladesh.

All clinical and follow-up data were prospectively collected in a pre-designed data collection form. After processing of all available data, statistical analysis of their significance was done. Obtained data were expressed in frequency, percentage, mean and standard deviation as applicable. Comparison between groups was done by Student's t-test for continuous variables. Categorical data were analyzed by Chi-square test and Fisher's exact test (as appropriate). The whole analyses were done with the help of computer based SPSS (Statistical Programme for Social Science) programme version 16.0. pvalue of $<0.05$ was considered as significant.

\section{Results:}

The mean age of group I patients was 60.4 years and 49.9 years for group II patients. Hypertension was the commonest risk factor in both groups ( $75 \%$ vs. $40.6 \%$ ). $37.5 \%$ of CKD patients complaints of shortness of breath during admission. But this complaint was $18.8 \%$ in patients with normal renal function.

\section{Table-I}

Distribution of the demographic profiles between the groups

\begin{tabular}{|c|c|c|c|c|c|}
\hline \multirow[t]{2}{*}{$\begin{array}{l}\text { Age group } \\
\text { (years) }\end{array}$} & \multicolumn{2}{|c|}{$\begin{array}{l}\text { Group I } \\
(n=64)\end{array}$} & \multicolumn{2}{|c|}{$\begin{array}{c}\text { Group II } \\
(\mathrm{n}=64)\end{array}$} & \multirow[t]{2}{*}{ p value* } \\
\hline & $\overline{\mathrm{n}}$ & $\%$ & $\mathrm{n}$ & $\%$ & \\
\hline$£ 40$ & 0 & 0 & 11 & 17.2 & \\
\hline $41-50$ & 7 & 11 & 30 & 46.9 & \\
\hline $51-60$ & 29 & 45.3 & 15 & 23.4 & \\
\hline $61-70$ & 20 & 31.2 & 8 & 12.5 & \\
\hline$\geq 71$ & 8 & 12.5 & 0 & 0 & \\
\hline Mean \pm SD & \multicolumn{2}{|c|}{$60.4 \pm 8$} & \multicolumn{2}{|c|}{$49.9 \pm 9.3$} & $.001^{\mathrm{S}}$ \\
\hline Range & \multicolumn{2}{|c|}{$45-74$} & \multicolumn{2}{|c|}{$31-70$} & \\
\hline
\end{tabular}

Group I = NSTEMI with CKD, Group II = NSTEMI without CKD, $\mathrm{S}=$ Significant

* t-test was done to measure the level of significance

\section{Table-II}

Distribution of risk factors between the groups $(n=128)$

\begin{tabular}{|c|c|c|c|c|c|}
\hline \multirow[t]{2}{*}{$\begin{array}{l}\text { Risk } \\
\text { factor }\end{array}$} & \multicolumn{2}{|c|}{$\begin{array}{l}\text { Group I } \\
(\mathrm{n}=64)\end{array}$} & \multicolumn{2}{|c|}{$\begin{array}{c}\text { Group II } \\
(\mathrm{n}=64)\end{array}$} & \multirow[t]{2}{*}{$\mathrm{p}$ value* } \\
\hline & $\overline{\mathrm{n}}$ & $\%$ & $\mathrm{n}$ & $\%$ & \\
\hline $\begin{array}{l}\text { Smoking } \\
\text { Current } \\
\text { Smoker }\end{array}$ & 23 & 35.9 & 23 & 35.9 & $.425^{\mathrm{NS}}$ \\
\hline $\begin{array}{l}\text { Ex-smoker } \\
\text { Non-smoker }\end{array}$ & $\begin{array}{l}29 \\
12\end{array}$ & $\begin{array}{l}45.3 \\
18.8\end{array}$ & $\begin{array}{c}7 \\
34\end{array}$ & $\begin{array}{c}11 \\
53.1\end{array}$ & \\
\hline $\begin{array}{l}\text { Hypertensio } \\
\text { Yes } \\
\text { No }\end{array}$ & $\begin{array}{l}48 \\
16\end{array}$ & $\begin{array}{l}75 \\
25\end{array}$ & $\begin{array}{l}26 \\
38\end{array}$ & $\begin{array}{l}40.6 \\
59.4\end{array}$ & $.001^{\mathrm{S}}$ \\
\hline $\begin{array}{l}\text { Dyslipidaem } \\
\text { Yes } \\
\text { No }\end{array}$ & $\begin{array}{l}\mathrm{a} \\
37 \\
27\end{array}$ & $\begin{array}{l}57.8 \\
42.2\end{array}$ & $\begin{array}{l}25 \\
39\end{array}$ & $\begin{array}{l}39.1 \\
60.9\end{array}$ & $.052^{\mathrm{NS}}$ \\
\hline $\begin{array}{l}\text { Family H/O I } \\
\text { Yes } \\
\text { No }\end{array}$ & $\begin{array}{r}H D \\
14 \\
50\end{array}$ & $\begin{array}{l}21.9 \\
78.1\end{array}$ & $\begin{array}{l}14 \\
50\end{array}$ & $\begin{array}{l}21.9 \\
78.1\end{array}$ & $1.000^{\mathrm{NS}}$ \\
\hline Diabetes me & litus & & & & \\
\hline $\begin{array}{l}\text { Yes } \\
\text { No }\end{array}$ & $\begin{array}{l}42 \\
22 \\
\end{array}$ & $\begin{array}{l}65.6 \\
34.4 \\
\end{array}$ & $\begin{array}{l}17 \\
47 \\
\end{array}$ & $\begin{array}{l}26.6 \\
73.4 \\
\end{array}$ & $.001^{\mathrm{S}}$ \\
\hline
\end{tabular}

Group I = NSTEMI with CKD, Group II = NSTEMI without $\mathrm{CKD}, \mathrm{NS}=$ Not Significant

$\mathrm{S}=$ Significant. ${ }^{*}$ Chi-square test was done to measure the level of significance 
Table-III

Clinical presentation of the study patients $(n=128)$

\begin{tabular}{lcccccc}
\hline Variable & \multicolumn{2}{c}{$\begin{array}{c}\text { Group I } \\
(\mathrm{n}=64)\end{array}$} & & \multicolumn{2}{c}{$\begin{array}{c}\text { Group II } \\
(\mathrm{n}=64)\end{array}$} & $\mathrm{p}$ value* \\
\cline { 2 - 3 } & $\mathrm{n}$ & $\%$ & & $\mathrm{n}$ & $\%$ & \\
\hline Chest pain & & & & & & \\
Present & 44 & 68.8 & 53 & 82.8 & $.063^{\mathrm{NS}}$ \\
Absent & 20 & 31.2 & 11 & 17.2 & \\
Shortness of breath & & & & & \\
Present & 24 & 37.5 & 12 & 18.8 & $.018^{\mathrm{S}}$ \\
Absent & 40 & 62.5 & 52 & 81.2 & \\
Others & & & & & & \\
Present & 11 & 17.2 & 14 & 21.9. & $504^{\mathrm{NS}}$ \\
Absent & 53 & 82.8 & 50 & 78.1 & \\
\hline
\end{tabular}

Group I = NSTEMI with CKD, Group II = NSTEMI without CKD, NS = Not Significant

$\mathrm{S}=$ Significant. $\quad$ *Chi-square test was done to measure the level of significance

The mean left ventricular ejection fraction of group I patients was $54.8 \%$ and $58.5 \%$ for group II patients. The mean value of serum creatinine and estimated glomerular filtration rate was 1.7 $\mathrm{mg} / \mathrm{dl}$ and $40.4 \mathrm{ml} / \mathrm{min} / 1.73 \mathrm{~m}^{2}$ respectively in CKD group and $1.0 \mathrm{mg} / \mathrm{dl}$ and $76.3 \mathrm{ml} / \mathrm{min} / 1.73 \mathrm{~m}^{2}$ respectively in non-CKD group. The mean value of $\mathrm{Hb} \%$ was 11.1 and $12.1 \mathrm{gm} / \mathrm{dl}$ in group I and group II respectively.

\section{Table-IV}

Distribution of the study patients $(n=128)$ by mean ejection fraction

\begin{tabular}{|c|c|c|c|c|c|}
\hline \multirow[t]{2}{*}{$\overline{\mathrm{LVEF} \%}$} & \multicolumn{2}{|c|}{$\begin{array}{c}\text { Group I } \\
(\mathrm{n}=64)\end{array}$} & \multicolumn{2}{|c|}{$\begin{array}{c}\text { Group II } \\
(\mathrm{n}=64)\end{array}$} & \multirow[t]{2}{*}{$\mathrm{p}$ value* } \\
\hline & $\bar{n}$ & $\overline{\%}$ & $\bar{n}$ & $\overline{\%}$ & \\
\hline$\leq 40$ & 6 & 9.4 & 0 & 0 & \\
\hline $41-50$ & 10 & 15.6 & 9 & 14.1 & \\
\hline $51-60$ & 36 & 56.2 & 28 & 43.8 & \\
\hline$\geq 61$ & 12 & 18.8 & 27 & 42.2 & \\
\hline Mean \pm SD & \multicolumn{2}{|c|}{$54.8 \pm 7.8$} & \multicolumn{2}{|c|}{$58.5 \pm 7.5$} & $.009^{\mathrm{S}}$ \\
\hline Range & \multicolumn{2}{|c|}{$35-66$} & \multicolumn{2}{|c|}{$42-70$} & \\
\hline
\end{tabular}

Group I = NSTEMI with CKD, Group II = NSTEMI without CKD, $\mathrm{S}=$ Significant

*t -test was done to measure the level of significance
Table-V

Distribution of the study patients $(n=128)$ by mean serum creatinine and estimated GFR

\begin{tabular}{|c|c|c|c|c|c|}
\hline \multirow[t]{2}{*}{ Variable } & \multicolumn{2}{|c|}{ Group I $(n=64)$} & \multicolumn{2}{|c|}{ Group II $(n=64)$} & \multirow[t]{2}{*}{ p value* } \\
\hline & Mean \pm SD & Range & $\mathrm{Mean} \pm \mathrm{SD}$ & Range & \\
\hline $\begin{array}{l}\text { Serum } \\
\text { creatinine } \\
(\mathrm{mg} / \mathrm{dL})\end{array}$ & $1.7 \pm 0.2$ & $1.5-2.8$ & $1.0 \pm 0.1$ & $0.7-1.4$ & $.001^{\mathrm{S}}$ \\
\hline $\begin{array}{l}\text { Estimated } \\
\text { glomerular } \\
\text { filtration rate } \\
(\mathrm{mL} / \mathrm{min} / \\
\left.1.73 \mathrm{~m}^{2}\right)\end{array}$ & $\begin{array}{l}40.4 \pm 8.8 \\
\text { te }\end{array}$ & $23-59$ & $76.3 \pm 1.4$ & $60.7-131.9$ & $.001^{\mathrm{S}}$ \\
\hline $\begin{array}{l}\mathrm{Hb} \% \\
(\mathrm{gm} / \mathrm{dL})\end{array}$ & $11.1 \pm 1.2$ & $8-13.2$ & $12.1 \pm 1.1$ & $10-15$ & $.001^{\mathrm{S}}$ \\
\hline
\end{tabular}

Group I = NSTEMI with CKD, Group II = NSTEMI without CKD , S = Significant

${ }^{*}$ t -test was done to measure the level of significance

$32.8 \%$ of patients in group I and $14.1 \%$ patients in group II developed complications during their hospital stay. The development of heart failure (15.6\%) and acute kidney injury (12.5\%) were significantly higher among patients with CKD compared to those with normal renal function. Other complications, such as, persistent chest pain, cardiogenic shock and arrhythmias were also higher in CKD group, though not statistically significant. Among CKD patients, 3.1\% died during their hospital stay. On the other hand, all the patients with normal renal function survived.

Table-VI

Distribution of the study patients $(n=128)$ by duration of stay

\begin{tabular}{lccc}
\hline Variable & $\begin{array}{c}\text { Group I (n=64) } \\
\text { Mean } \pm \text { SD }\end{array}$ & $\begin{array}{c}\text { Group II (n=64) } \\
\text { Mean } \pm \text { SD }\end{array}$ & p value* \\
\hline CCU stay (days) & $2.4 \pm 2$ & $1.7 \pm 1.4$ & $.001^{\mathrm{S}}$ \\
Hospital stay (days) & $6.6 \pm 4$ & $5.2 \pm 3.1$ & $.001^{\mathrm{S}}$ \\
\hline
\end{tabular}

Group I = NSTEMI with CKD,Group II = NSTEMI without $\mathrm{CKD}, \mathrm{S}=$ Significant

*t $\mathrm{t}$-test was done to measure the level of significance

Table-VII

Distribution of the study patients $(n=128)$ by in-hospital complications

\begin{tabular}{|c|c|c|c|c|c|}
\hline \multirow[t]{2}{*}{ Complication } & \multicolumn{2}{|c|}{$\begin{array}{l}\text { Group I } \\
(\mathrm{n}=64)\end{array}$} & \multicolumn{2}{|c|}{$\begin{array}{c}\text { Group II } \\
(\mathrm{n}=64)\end{array}$} & \multirow[t]{2}{*}{$\mathrm{e}^{*}$} \\
\hline & $\mathrm{n}$ & $\overline{\%}$ & $\overline{\mathrm{n}}$ & $\overline{\%}$ & \\
\hline Present & 21 & 32.8 & 9 & 14.1 & $.012^{\mathrm{S}}$ \\
\hline Absent & 43 & 67.2 & 55 & 85.9 & \\
\hline
\end{tabular}

Group I = NSTEMI with CKD, Group II = NSTEMI without CKD, S = Significant

*Chi-square test was done to measure the level of significance 
Table-VIII

Distribution of selected variables by inhospital complications

\begin{tabular}{lccc}
\hline Variable & \multicolumn{2}{c}{ Complication } & p value\# \\
\cline { 2 - 3 } & $\begin{array}{c}\text { Present } \\
(\mathrm{n}=30)\end{array}$ & $\begin{array}{c}\text { Absent } \\
(\mathrm{n}=98)\end{array}$ & \\
\hline Age (years) & $59.2 \pm 11^{*}$ & $53.9 \pm 9.6$ & $.012^{\mathrm{S}}$ \\
Hb\% (gm/dL) & $11.1 \pm 1.3$ & $11.8 \pm 1.3$ & $.015^{\mathrm{S}}$ \\
LVEF(\%) & $53.6 \pm 8.3$ & $57.6 \pm 7.5$ & $.015^{\mathrm{S}}$ \\
HTN & $22(73.3)^{*}$ & $52(53.1)$ & $.049^{\mathrm{S}}$ \\
DM & $17(56.7)$ & $42(42.9)$ & $.184^{\mathrm{NS}}$ \\
\hline
\end{tabular}

*values indicate mean $\pm \mathrm{SD}, \mathrm{S}=$ Significant, \# t - test was done to measure the level of significance

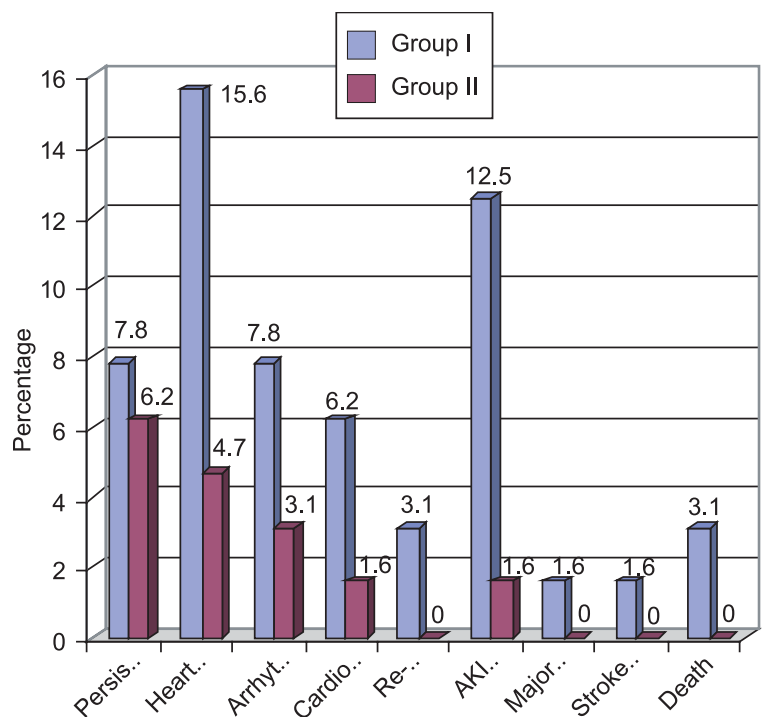

Fig.-1: Bar diagram showing distribution of the study patients $(n=128)$ by in-hospital outcomes

Among various factors, univariate analysis showed that presence of hypertension $(73.3 \%$ vs. $53.1 \%$; p<0.05), age $(59.2 \pm 11$ years vs. $53.9 \pm 9.6$ years; $\mathrm{p}<0.05), \mathrm{Hb} \%(11.11 \pm 1.3 \mathrm{gm} / \mathrm{dL}$ vs. $11.8 \pm 1.3$ $\mathrm{gm} / \mathrm{dL} ; \mathrm{p}<0.05), \mathrm{LVEF} \%$ (53.6 $\pm 8.8 \%$ vs. $57.6 \pm 7.5 \%$; $\mathrm{p}<0.05$ ) were found to be important determinants of in-hospital complications. A step wise binary regression model was done with in-hospital complications as dependent and CKD group, age, $\mathrm{HTN}, \mathrm{LVEF} \%$ and $\mathrm{Hb} \%$ as independent variables. However, only CKD remain in the final model in stepwise logistic regression. CKD patients had 2.98 times higher risk of developing in-hospital complications.
Table-IX

Result of multiple logistic regression analysis

\begin{tabular}{lccccc}
\hline Variable & B & Wald & $\begin{array}{c}\text { Odds } \\
\text { ratio }\end{array}$ & $\begin{array}{c}95.0 \% \text { C.I. } \\
\text { for odds } \\
\text { ratio }\end{array}$ & p value \\
\hline Constant & -1.26 & 31.89 & 0.28 & - & .001 \\
Presence & 1.09 & 5.97 & 2.98 & $1.24-7.17$ & .015 \\
of CKD & & & & & \\
\hline
\end{tabular}

\section{Discussion:}

This was a prospective observational study. By analyzing the estimated GFR using the Cockroft and Gault formula, patients were categorized in two groups: group I - patients with NSTEMI with CKD and Group II - patients with NSTEMI with normal renal function. A total of 128 patients were included in this study.

When age of the study patients were compared between the groups, it was found that the mean age in group I was $60.4 \pm 8$ years and group II was $49.9 \pm 9.3$ years. Mean age difference was statistically significant $(\mathrm{p}<0.05)$ between the groups. Nearly similar pattern of age distribution was reported in different studies in Bangladesh like Pasha and Awal, et al.4,8 It was evident from the study that patients with CKD tended to be older than those with normal renal function. This observation was being consistent with the findings of different studies done in foreign countries. $1,9,10,11,12$

Hypertension was the commonest risk factor in both groups. Wong, et al. found that among NSTEMI patients with kidney dysfunction $62.2 \%$ were hypertensive, $45.6 \%$ were diabetic, $31.3 \%$ were dyslipidaemic and $14.6 \%$ were current smoker in Canadian ACS I registry. ${ }^{10}$ Sarnak, et al., El-Menyar, et al., Fox, et al. and Kosuge, et al. observed hypertension as a commonest risk factor in their respective study. ${ }^{1,12,14,15}$ So, the prevalence of risk factors in the present study was comparable with other studies.

During admission, chest pain was the presenting complaint in $68.8 \%$ in group I and $82.8 \%$ in group II. Absence of chest pain was higher (31.2\%) in group I than in group II $(17.2 \%)$. But the difference was not statistically significant ( $p>0.05)$. Shortness of breath was found $37.5 \%$ in group I and $18.8 \%$ in group II which was statistically significant $(p<0.05)$. El-Menyar, et 
al. observed that $26 \%$ of patients with chronic renal insufficiency complaints of shortness of breath and they were less likely to have chest pain at presentation which was statistically significant $(p<0.001) .{ }^{12}$ Finding of El-Menyar, et al. was consistent with this finding in that atypical presentation was more in patients with CKD than those without CKD. This was attributed to the fact that diabetic autonomic neuropathy or uraemic neuropathy, which may impair sensation of myocardial ischaemic pain, was more common among patients in NSTEMI with renal dysfunction.

The mean left ventricular ejection fraction was $54.8 \pm 7.8 \%$ in group I and $58.5 \pm 7.5 \%$ in group II. Mean ejection fraction was lower in group I than group II. This difference was statistically significant $(p<0.05)$. Pasha also showed that mean ejection fraction was significantly lower in patients with impaired renal function than those with normal renal function $(47.9 \pm 6.3 \%$ vs. $52.0 \pm 5.2 \%){ }^{4}$ Kang, Jeong and Kim found that patients with NSTEMI with renal dysfunction

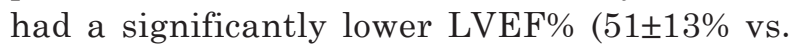
$58 \pm 10 \%) .{ }^{9}$ So, their findings were consistent with the findings of this study in that patients with CKD have reduced LVEF\% than those with normal renal function.

The mean value of serum creatinine and estimated glomerular filtration rate were $1.7 \pm 0.2$ $\mathrm{mg} / \mathrm{dL}$ and $40.4 \pm 8.8 \mathrm{~mL} / \mathrm{min} / 1.73 \mathrm{~m}^{2}$ respectively in group I and $1 \pm 0.1 \mathrm{mg} / \mathrm{dL}$ and $76.3 \pm 1.4 \mathrm{~mL} /$ $\mathrm{min} / 1.73 \mathrm{~m}^{2}$ respectively in group II. These differences were statistically significant $(\mathrm{p}<0.001)$. Hossain found identical mean serum creatinine and creatinine clearance rate $(1.73$ $\mathrm{mg} / \mathrm{dL}$ and $39.9 \mathrm{~mL} / \mathrm{min}$ respectively in $80 \mathrm{CKD}$ patients) with the current study. ${ }^{12}$ Nearly similar pattern of mean serum creatinine and estimated glomerular filtration rate distribution were reported in different studies like Kang, Jeong and Kim, Wong, et al. and El-Menyar et al.9,10,12

Anaemia is common in CKD patients; it usually correlates with the severity of renal failure and contributes to many of the non-specific symptoms of $\mathrm{CKD}$. In this study, mean $\mathrm{Hb} \%$ was $11.1 \pm 1.2$ and $12.1 \pm 1.1 \mathrm{gm} / \mathrm{dL}$ in group I and group II respectively which was statistically significant $(\mathrm{p}<0.05)$. Hossain found mean $\mathrm{Hb} \%$ was $11.6 \mathrm{gm} /$ $\mathrm{dL}$ in $80 \mathrm{CKD}$ patients. ${ }^{13}$
This study demonstrated that patients with NSTEMI and CKD had a relatively longer hospital stay than those with normal renal function. Mean length of CCU stay was $2.4 \pm 2$ and $1.7 \pm$ 1.4 days in group I and group II respectively. Mean length of hospital stay was $6.6 \pm 4$ and 5.2 \pm 3.1 days in group I and group II respectively. Statistically significant difference was found between the groups in terms of mean CCU stay and hospital stay $(p<0.001)$. Nearly similar pattern of mean CCU and hospital stay (days) were reported in different studies like Freeman, et al., Kang, Jeong and Kim and El-Menyar, et al. ${ }^{9,12,17}$ This finding demonstrates that CKD constitutes a further burden on hospital resources in patients with NSTEMI.

The total in-hospital complications were significantly higher in group I compared with those of group II. 21(32.8\%) patients in group I and $9(14.1 \%)$ patients in group II developed complications during their hospital stay. Kang, Jeong and Kim found 32(34\%) patients with renal dysfunction and 20(18.8\%) patients without renal dysfunction developed complications $(\mathrm{p}<0.001) .{ }^{9}$

In this study, the most frequent complications in group I were heart failure (15.6\%) followed by acute kidney injury (12.5\%), arrhythmias (7.8\%), persistent chest pain $(7.8 \%)$, cardiogenic shock (6.2\%), re-infarction (3.1\%), death (3.1\%), major bleeding (1.6\%) and stroke (1.6\%). The most frequent complications in group II were persistent chest pain $(9.4 \%)$ followed by heart failure $(4.7 \%)$, arrhythmia (3.1\%), cardiogenic shock (1.6\%) and AKI (1.6\%). There was statistically significant difference between the groups in terms of heart failure and acute kidney injury $(\mathrm{p}<0.05)$. Other complications were also higher in patients with CKD than those with normal renal function, though the difference was not statistically significant $(p>0.05)$. The lack of statistically significant difference between the groups might be due to small sample size. Moreover, high prevalence of comorbid conditions and metabolic derangements induced by the CKD state may contribute to poorer outcomes in patients with CKD after NSTEMI. 
El-Menyar, et al. found that heart failure was $32 \%$ vs. $9 \%$, cardiogenic shock was $7 \%$ vs. $2 \%$, major bleeding was $1.6 \%$ vs. $0.5 \%$ and stroke was $1.9 \%$ vs. $0.3 \%$ among the patients with and without CKD in their study $(\mathrm{p}<0.001) .{ }^{12}$ AKI was found in 12 patients; cardiogenic shock in 39 patients; major bleeding in 2 patients; arrhythmias in 13 patients with renal dysfunction while none had AKI; 15 had cardiogenic shock; 1 had major bleeding and 14 had arrhythmias with normal renal function in the study of Kang, Jeong and Kim. ${ }^{9}$

Higher prevalence of heart failure in CKD may be secondary to anaemia, volume overload and diastolic dysfunction. Pasha found heart failure was higher among patients with abnormal serum creatinine clearance $(25.3 \%)$ compared to that with normal serum creatinine clearance (3.7\%). ${ }^{4}$ Freeman, et al. in their study regarding ACS and renal dysfunction found $16 \%$ and $37 \%$ patients with heart failure who had normal and impaired renal function respectively. ${ }^{16}$ Fox, et al. found that patients with CKD were at higher risk of heart failure than patients with no CKD $(12.5 \%$ vs. $4.4 \%) .{ }^{1}$ All these findings were consistent with this finding in that heart failure was more in patients with CKD than those with normal renal function.

According to Acute Kidney Injury Network, 2007 an abrupt (within 48 hours) reduction in kidney function currently defined as an absolute increase in serum creatinine of more than or equal to $0.3 \mathrm{mg} / \mathrm{dl}$, a percentage increase in serum creatinine of more than or equal to $50 \%$ (1.5 fold from baseline). Among 8 patients in group I who developed AKI, 5 patients developed AKI following admission and remaining 3 patients developed AKI following coronary interventions. Goldberg, et al. and Parikh, et al. found $9.6 \%$ and $19.4 \%$ of patients developed AKI during their hospital stay. ${ }^{17,18} \mathrm{Lo}$, Liu and Hsu suggested that the association between AKI and adverse outcomes exists because patients who develop AKI have more severe pre-existing CKD than subjects who do not experience AKI. CKD also increases the risk of developing AKI after an acute illness. ${ }^{19}$

It is reported that around $14.5 \%$ of patients develop CIN (a form of AKI) after coronary angiography and intervention that results from both renal tubular toxicity and renal medullary ischaemia. ${ }^{8}$ The most important risk marker for nephropathy after exposure of contrast media is pre-existing renal impairment and diabetes mellitus. Other markers associated with an increased risk of CIN include nephrotoxic drugs, anaemia, older age, preprocedural haemodynamic instability, volume depletion, heart failure and hypoalbuminaemia. ${ }^{20}$

In this condition, acute heart disease with ischemic injury (e.g., NSTEMI) might induce AKI through complex mechanisms, including hemodynamically mediated damage secondary to impaired cardiac output, anaemia, exogenous factors such as the contrast media used in coronary intervention, nephrotoxic effect of drugs (diuretics and rennin-angiotensinaldosterone inhibitors), and humoral and immune-mediated damage to the kidney. These factors triggered activation of renal sympathetic nervous system which may contribute to decreased GFR with acute kidney hypo perfusion, reduced oxygen delivery, increased resistance to atrial natriuretic peptide and Btype natriuretic peptide, and increased cellular necrosis and apoptosis. Potential presences of a residual confounding factor in patients with CKD have been proposed to explain this clinically unfavorable association in subjects with NSTEMI developing AKI.

Freeman, et al. showed that ACS patients with abnormal renal function had significantly higher mortality compared to those with no renal impairment. ${ }^{16}$ Pasha noticed death of $6(9.5 \%)$ patients with impaired renal function. ${ }^{4}$ The mortality rate was $8 \%$ in patients with CKD compared with only $3.1 \%$ in patients without CKD in the study of Charytan, et al. ${ }^{21}$ The estimated in-hospital death in patients with or without CKD was $16.8 \%$ and $0.8 \%$, respectively, in the study of Kang, Jeong and Kim. ${ }^{9}$ In hospital mortality was $6 \%$ vs. $0.7 \%$ in NSTEMI patients with or without chronic renal insufficiency in the study of El-Menyar, et al. which was statistically significant $(p<0.001) .{ }^{12}$ Several key articles described the increased mortality of patients with CKD in the acute MI setting and the relative underutilization of known cardio 
protective therapies compared with patients without CKD. ${ }^{1}$

In this study, two patients (3.1\%) died in group I. One patient was suffering from severe left main with double vessel coronary artery disease. Another patient was suffering from left main with triple vessel coronary artery disease with complete heart block. Both of them were waiting for CABG. Mortality rate was zero in group II and the difference between the groups in terms of mortality was not statistically significant $(p>0.05)$. Small sample size and use of early invasive strategy in the study populations may explain this.

\section{Conclusions:}

CKD strongly predicts adverse in-hospital outcome among NSTEMI patients. Compared to patients with normal renal function, CKD patients were significantly older, with a greater prevalence of hypertension, lower left ventricular ejection fraction and lower haemoglobin level. CKD patients had more atypical presentation during admission. Inhospital complications were significantly higher in CKD patients presenting with NSTEMI.

\section{Study limitations:}

Sample size was small. All the patients with NSTEMI with CKD were not included due to different contraindications and co-morbid conditions. Follow-up was done only during hospital stay. Serum creatinine value might have been influenced by medications or clinical status.

Conflict of Interest - None.

\section{References:}

1. Fox CS, Muntner P, Chen AY, Alexander KP, Roe MT, Cannon CP, Saucedo JF, Kontos MC, Wiviott SD. Use of Evidence-Based Therapies in Short-Term Outcomes of STSegment Elevation Myocardial Infarction and Non STSegment Myocardial Infarction in Patients With Chronic Kidney Disease. Circulation 2010; 121: 357-365.

2. Faruque M, Islam AEMM, Rashid MA, Haque MS, Rahman F, Kibria MG, Khan HILR. Coronary artery disease in patients with chronic kidney disease- a review. Cardiovasc j 2008; 1(1):97-104.

3. Chonchol M, Whittle J, Desbien A, Orner MB, Petersen LA, Kressin NR. Chronic kidney disease is associated with angiographic coronary artery disease. American Journal of Nephrology 2008; 28: 354-360.
4. Pasha K. In-hospital outcome of patients of acute STEMI with impaired renal function. Thesis MD (Cardiology), National Institute of Cardiovascular Diseases (NICVD), Dhaka. 2004.

5. Anderson JL, Adams CD, Antman EM, Bridges CR, Califf RM, Casey DE, Chavey WE, Fesmire FM, Hochman JS, Levin TN, Lincoff AM, Peterson ED, Theroux P, Wenger NK, Wright RS. 2011 ACCF/AHA 2007 Focused Update Incorporated into ACC/AHA 2007 guidelines for the management of patients with unstable angina/non-STelevation myocardial infarction: a report of the American College of Cardiology/ American Heart Association Task Force on Practice Guidelines. Circulation 2011; 123: 1154.

6. K/DOQI clinical practice guidelines for chronic kidney disease: Evaluation, classification, and stratification. American Journal of Kidney Disease 2002; 39: 1-266.

7. Cockcroft DW, Gault MH. Prediction of creatinine clearance from serum creatinine. Nephron 1976; 16(1):3141.

8. Awal A, Hasan SA, Siddique MA, Subedi B, Arzu J, Ahmed QA, Haque KMHSS, Sultan MAU, Islam N. N-Acetyl cystine for prevention of contrast induced nephropathy. University Heart Journal 2009; 5(2): 57-59.

9. Kang YU, Jeong MH, Kim SW. Impact of Renal Dysfunction on Clinical Outcomes of Acute Coronary Syndrome. Yonsei Medical Journal 2009; 50(4):537-545.

10. Wong JA, Goodman SG, Yan RT, Wald R, Bagnall AJ, Welsh RC, Wong GC, Kornder J, Eagle KA, Steg PG, Yan T. Temporal management patterns and outcomes of nonST elevation acute coronary syndromes in patients with kidney dysfunction. European Heart Journal 2009; 30(5): 549-557.

11. Na KY, Kim CW, Song YR, Chin HJ, Chae DW. The Association between Kidney Function, Coronary Artery Disease, and Clinical Outcome in Patients Undergoing Coronary Angiography. Journal of Korean Medical Science 2009; 24(1): 87-94.

12. El-Menyar A, Zubaid M, Singh R, Sulaiman K, Thani HA, Akbar M, Bulbanat B, Hamdan RA, Mahmmed WA, Suwaidi JA. In-hospital Major Clinical Outcomes in Patients With Chronic Renal Insufficiency Presenting With Acute Coronary Syndrome: Data From a Registry of 8176 Patients. Mayo Clinic Proceedings 2010; 85(4): 332-340.

13. Hossain MS. Comparison of nephrotoxic effect of isoosmolar and low-osmolar non-ionic contrast media in patient with chronic kidney disease undergoing coronary angiography. Thesis MD (cardiology), National Heart Foundation Hospital \& Research Institute (NHFH \& RI), Dhaka. 2010.

14. Sarnak MJ, Levey AS, Schoolwerth AC, Coresh J, Culleton B, Hamm LL, McCullough PA, Kasiske BL, Kelepouris E, Klag MJ, Parfrey P, Pfeffer M, Raij L, Spinosa DJ, Wilson PW. Kidney disease as a risk factor for development of cardiovascular disease- a statement from the American Heart Association councils on kidney in cardiovascular 
disease, high blood pressure research, clinical cardiology, and epidemiology and prevention. Hypertension 2003; 108:2154-2169.

15. Kosuge M, Ebina T, Hibi K, Morita S, Endo M, Maejima N, Iwahashi N, Okada K, Ishikawa T, Umemuta S, Kimura K. An Early and Simple Predictor of Severe Left Main and/or Three-Vessel Disease in Patients with Non-STSegment Elevation Acute Coronary Syndrome. Am J Cardiol 2011; 107:495-500.

16. Freeman RV, Mehta RH, Badr WA, Cooper JV, Rogers EK. Influence of concurrent renal dysfunction on outcome of patients with acute coronary syndromes and implications of the use of glycoprotein IIb/IIIa inhibitors. J Am Coll Cardiol 2003; 41: 718-724.

17. Goldberg A, Kogan E, Hammerman H, MarkiewiczW, Aronson D. The impact of transient and persistent acute kidney injury on long-term outcomes after acute myocardial infarction. Kidney International 2009; 76:900-906.
18. Parikh CR, Coca SG, Wang Y, Masoudi FA, Krumholz HM. Long-term prognosis of acute kidney injury after acute myocardial infarction. Archives of Internal Medicine 2008; 168(9): 987-995.

19. Lo L, Liu KD, Hsu CY. Long-term outcomes after acute kidney injury: Where we stand and how we can move forward. American Journal of Kidney Disease 2009; 53(6):928-931.

20. Masud T, McClellan WM. The Heart and Kidney Disease. In: V. Fuster, R. A. O’Rourke, R.A. Walsh, P. Poole-Wilson, eds. Hurst's The Heart. New York: McGraw - Hill, 2008: 2209-2224.

21. Charytan DM, Wallentin L, Lagerqvist B, Spacek R, De Winter RJ, Stern NM, Braunwald E, Cannon CP, Choudhry NK. Early Angiography in Patients with Chronic Kidney Disease: A Collaborative Systematic Review. Clinical Journal of the American Society of Nephrology 2009; 4:1032-1043. 